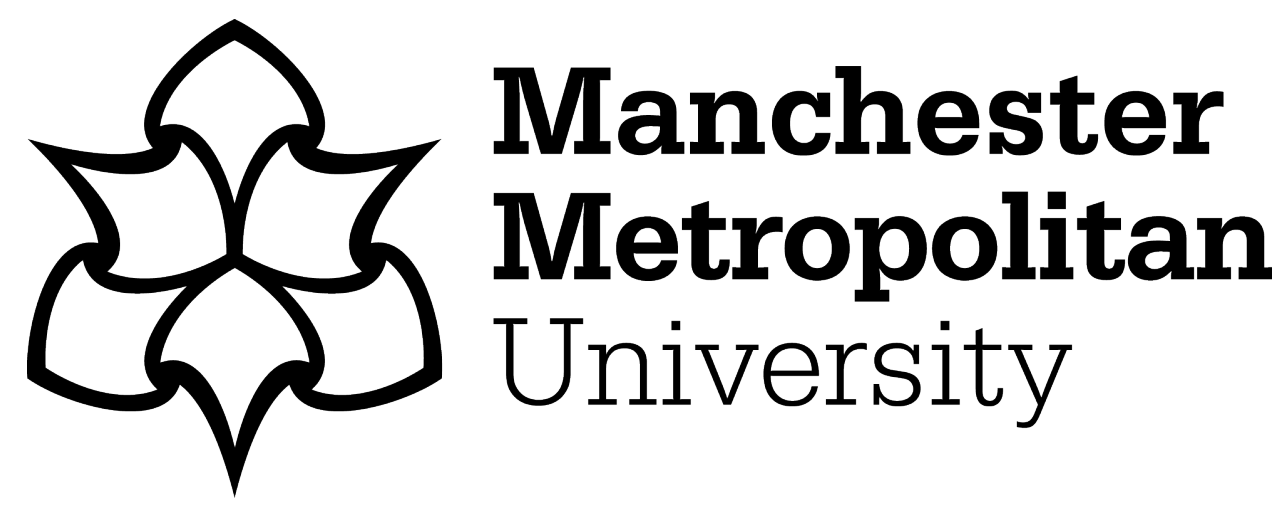

Csepely-Knorr, Luca ORCID logoORCID: https://orcid.org/0000-0003-10921447 and Klagyivik, Maria (2020) From Social Spaces to Training Fields: Changes in Design Theory of the Children's Public Sphere in Hungary in the First Half of the 20th Century. Childhood in the Past, 13 (2). pp. 93-108. ISSN $1758-5716$

Downloaded from: https://e-space.mmu.ac.uk/625841/

Version: Accepted Version

Publisher: Taylor \& Francis (Routledge)

DOI: https://doi.org/10.1080/17585716.2020.1791495

Please cite the published version 
From Social Spaces to Training Fields: Evolution of Design Theory of the Children's Public Sphere in Hungary in the First Half of the $\mathbf{2 0}^{\text {th }}$ Century

Dr Luca Csepely-Knorr

Reader in Architecture, Manchester School of Architecture, Office 808, Chatham Building, Cavendish Street, Manchester, M15 6BR, United Kingdom

Email: 1.csepely-knorr@mmu.ac.uk, tel: +44 1612476924

Dr Mária Klagyivik

Landscape Architect, Hungarian Heritage Protection and Development Nonprofit Ltd., 3 Daróczi út, Budapest, H-1113, Hungary

Email: maria.klagyivik@gmail.com, tel: +36 205109679 


\section{From Social Spaces to Training Fields: Evolution of Design Theory of the Children's Public Sphere in Hungary in the First Half of the $\mathbf{2 0}^{\text {th }}$ Century}

The first half of the $20^{\text {th }}$ century brought turbulent changes into the political and social scene of Hungary. Within a few decades the country shifted from being a partner in the Austro-Hungarian Monarchy, to the short-lived Hungarian Soviet Republic, thereafter, the creation of the independent Kingdom of Hungary, which, after the WW2 ultimately became the People's Republic of Hungary. These changes strongly affected the main ideologies of all fields of life in the country, including architectural, landscape architectural and educational theory and practice. This paper discusses evolving Hungarian ideas about designing places for children in the international context of education. It follows the changing concepts of play space, from designing for physical education and health, to the idea of training soldiers for an approaching war. By tracing the intricate links between these ideas and the history of Hungary during the period between the turn of the $20^{\text {th }}$ century and the beginning of WW2, the paper argues that the interwoven nature of design theory and the socio-political context of children's spaces is key in understanding their development.

Keywords: playground; school play areas; Hungary; children's health

\section{Introduction}

In this paper we will introduce a key period in the development of the children's public sphere in Hungary: the decades of the late $19^{\text {th }}$ and early $20^{\text {th }}$ centuries. This period not only brought major social and political changes to the country, but these were the formative decades in the evolving design theory of public open spaces. Specifically here, we will investigate the establishment of specialised spaces for children from private school grounds and semi-private play areas to the creation of fully public, specially designed and equipped playgrounds. We will also analyse, how a city-wide 
system of playgrounds was established for the Hungarian capital, and how the alterations of these spaces reflected the emerging campaigning activities of the public and the changing political situation of the country.

The question will be scrutinised from two distinct points of view. The evolution of public health and pedagogical ideas - that led to the establishment of specialised spaces for children firstly in schools, and later in public spaces - will be compared with its contemporary design theory, which created new principles for designing children's spaces that, in many cases, remain relevant. Therefore, this paper aims to merge the design-centered and the child-centered methodologies, identified by Kozlovsky (2013, 3). Through this methodology, the paper will contribute to the histories of playgrounds as spatial entities, as well as to the broader histories of organised play (Howell 2008). By contextualising theoretical questions in the changing socio-political situation of Hungary at the time, this paper will investigate how the political and historical changes altered the main aims of creating places for young citizens: from the principle to create healthy environments, towards the goal of training soldiers for an upcoming war. It will discuss the evolution of ideas in two separate periods, using the WW1 as a distinct fissure. The decades before WW1 were a period of exceptional progress in Hungary. This time not only saw the rapid growth of a new capital, with new public spaces that determined a new theoretical approach in design, but it also laid the foundation of new public amenities and a new understanding and thinking about public health, including the mental and physical health of children. WW1 changed the governmental system of the country and had a huge effect in all spheres of public life. The interwar period, that will be discussed in the second half of the paper, saw the changes between left- and right-wing political thoughts that brought new understanding to childhood education and the role public spaces played in it. Key examples discussed in this paper are drawn 
from Budapest, the capital of Hungary. Budapest, as the biggest, most dense and rapidly evolving city, faced immense pressure to solve public health issues, and therefore the evolution of the theory of children's play areas in relation to realised examples is best observed here. Other Hungarian cities subsequently followed the established precedent of the capital.

\section{The pre-war era}

\section{Historical context and the first play-areas in Budapest}

In 1867 the King of Hungary and Emperor of Austria, Franz Joseph I, signed the Compromise Act in order to secure peace in, and support from, Hungary. ${ }^{1}$ This act laid down the foundation stone of the Austro-Hungarian Monarchy. Hungary enjoyed a real economic boom in the following half a century that also led to the implementation of new policies, of earlier origin, that were set aside because of the country's political situation. The decades between the Compromise and WW1 were one of the most important periods in the development of the Hungarian capital. In 1873 the three former independent cities, Pest Buda and Óbuda were lawfully merged together, and the new capital, Budapest was born. This led to a rapid and large-scale development of public spaces and parks, as well as new road infrastructure and neighbourhoods. Under the

${ }^{1}$ The decades between 1848 and 1867, often called 'Period of Absolutism' followed the failed 1848 Hungarian Revolution of Independence. During the revolution Hungary became a constitutional monarchy, and instead of the former Diet a representative parliament was set up. After a year and a half, Austria succeeded in defeating Hungary with Russian help and Hungary experienced the toughest suppression after the defeat and the nation went into a silent but firm opposition. 
direction of the Head Gardener, Hans Christian Ilsemann (1852-1912), these parks provided the first public spaces devoted to children. (Figure 1.) However, these were not playgrounds in a sense we understand it today. Based on the example of the Kinderpark in Vienna, built in 1863, the first public park fully dedicated to younger citizens, these spaces gave the opportunity for children to freely use it, but without any specialised equipments (Loidl-Reisch 2007, 94-95). Rather than 'playgrounds', they were called 'children's play-areas'. Ilsemann's design for the small 'play-area' at Mátyás square in Hungary from 1897 shows a paved, circular centre space with trees planted in circular, geometrical order intended for free play. (Figure 2.) Although their design and equipment were not revolutionary, the socio-political aspects of spaces designated for children were important milestones in the evolution of playgrounds (Hagner 2004, 96). These places were also crucial in terms of the theoretical evolution of how to design spaces - and also cities - with future generations in mind. As Pérez de Arce $(2018,15)$ argued, in Camillo Sitte's milestone urban planning theory, public spaces with children's play areas and athletic grounds became crucial parts of the 'sanitary greenery' of the city.

\section{Evolution of the theory and spatial practices of children's spaces}

Parallel to other European countries, Hungarian children's spaces, that we call playgrounds today, developed outside of the public realm. The question first appeared

in relation to issues of health and education, addressing concerns around the mental and physical health of children and young people. The institutional forms of social care developed from the $19^{\text {th }}$ century in Europe, dealt not only with the problems of social differences, but with public health institutions including children's health, which was initially treated mainly through school health and school hygiene programmes (Katona 
2010, 199-200). The innovations of philanthropist movements that emphasized the importance of physical health (e.g. Christian Gotthilf Salzmann's or Johann Christoph Friedrich Guts-Muths's lifework) played a significant role in the ratification of compulsory gymnastics in schools in the second half of the $19^{\text {th }}$ century. ${ }^{2}$ Endeavours for children's physical health already began in the 1820's in Hungary, and physical training became compulsory for both boys and girls after the ratification of the Public Education Act in 1868, straight after the Compromise Act, that gave a level of independence to the Hungarian Governments in legal issues (Act XXXVIII of 1868 on Public Education, Hungary). Hungarian thinkers followed international trends, that, by the second half of the $19^{\text {th }}$ Century developed as a mixture of three key directions, the German 'Turnen', Swedish 'Gymnastics' and English 'Sport'. As Gertrud Pfister (2003, 77) argued, these ideas - originally closely linked to the national politics and ideologies of their countries of origin - were all decisive in the development of physical education in Europe as they transcended national borders.

The German gymnastics (the so-called Turnen Movement), created by Friedrich Ludwig Jahn (1778-1852) in 1811 (see, e.g., Ohmann [2008] for more about Jahn) was a revolutionary middle-class movement and a strict system of specific, mainly military exercises. During the 1860s when the German Empire was founded, 'Turnen' became more than just physical exercise, as the sessions also contained patriotic speeches, traditional songs and the celebration of German history. Such a patriotic approach was

\footnotetext{
${ }^{2}$ The Schnepfenthal Institute in Germany, founded by Salzmann and where Guts-Muths also worked, is often seen as the birthplace of modern gymnastics. Several works were published about their pedagogical methods (Salzmann 1796, 1808; Guts-Muths 1793, 1796).
} 
not only important in terms of physical health and military fitness, but also strongly contributed to the process of nation building (Krüger 1996, Pfister 2003). Swedish gymnastics, created by Pehr Henrik Ling and Hjalmar Ling, approached from the anatomical point of view, rather than the aforementioned political orientation. Ling defined different directions of gymnastics, such as 'military', 'educational', 'medical' and 'aesthetic (Pfister 2003).

Play, as a much freer and more spontaneous form of physical education, originated in Great Britain, where sport obtained more importance in public schools during the $19^{\text {th }}$ century, becoming compulsory in these educational institutions between 1850 and 1890 (Pfister 2003). With sport becoming increasingly popular outside schools as well, there were attempts to open school playgrounds to the general public (Conway 1991, 210). ${ }^{3}$ Free sport opportunities for all classes, including workers, arose with the opening of public parks in the UK and became a leading reason to visit parks and spaces for 'innocent athletic games' and later for specialised play areas for children (Elliot \& Fieldhouse 2000).

The American Playground Association had a leading role in developing the idea of inclusive playgrounds in the USA. Originating from the European idea of the 'sand garden' to improve the health and morality of slum children by 'improving their physical environment', the first of these spaces was built in Boston in 1885 by women of the Massachusetts Emergency and Hygiene Association (Spencer-Wood 1994). After the original success of the 'sand gardens', playgrounds and recreational centres were built in several cities in the following decades, creating inclusive spaces for school and other children and adults at the same time. American reformers aimed to use these

\footnotetext{
${ }^{3}$ For a contemporary account see: Farquharson 1885, 150-159.
} 
spaces as 'corrective environments' 'through which to direct the development of immigrant children towards idealised American gender roles', proving that, similarily to the German 'Turnen' movement, sport and play places were key environments to achieve social transformation (Gagen 2000, 600.; Howell 2008, 962). During the first decades of the $20^{\text {th }}$ century the American 'Reform Parks' became an example to follow across Europe (Mero 1908, Lesser 1927, Cranz 1991, Frost 2010). German publications, such as Harry Maasz's 'Der deutsche Volkspark der Zukunft', published in 1913 and Hugo Koch’s 'Gartenkunst im Städtebau' published in 1914 as well as strong professional links between Germany and Hungary were key in transmitting ideas from the USA to Hungary.

\section{Spaces for sport and play in Hungary before WWI}

Hungary - just like almost all other European countries - followed the development of sport theory, introducing the two types of gymnastics first, which was mingled with play from the 1880-90's. ${ }^{4}$ Play areas developed first in schools exclusively, although the theoretical emergence of school and public playgrounds coincided in time. ${ }^{5}$ The first known plan of a Hungarian school playground, designed by Károly Albert, gymnast in Kolozsvár, appeared in 1889. (Figure 3.) The play area was an empty field enclosed with alleys and shrubs. Albert divided it according to different functions, creating four

\footnotetext{
${ }^{4}$ Gymnastics did not spread in Great Britain to such an extent like in other countries, probably because ball games and other free games had long tradition in this country. Other European countries show similarities to Hungary.

${ }^{5}$ Playing fields or playgrounds in the schools were made especially for schools, a playground could be used by more schools, according to a strict schedule. Children outside these schools could not enter in this period. On the other hand, public playgrounds in the parks if they had been existing at this time - could have been open for everyone.
} 
separate parts for ball games and skittles and leaving place for running and free play. On the other side of the plan he introduced an enclosed play space at the edge of the playground which could be used in rain, and also for dressing rooms, storage and toilets (Felméry 1889, 81-83). This spatial arrangement of empty areas for free use became a widespread example in the creation of play-areas.

Compulsory play-afternoons were introduced in secondary schools as part of the widening child-welfare programmes in the school year 1900/1901, that also encouraged the installation of supervised school playgrounds, of which, several examples were realised after the turn of the $20^{\text {th }}$ century. ${ }^{6}$ The question of creating new spaces to satisfy the requirements of new trends of physical training in schools moved quickly towards social concerns. Although play afternoons created a solution for the daycare of children who attended the schools that belonged to the actual playground, it did not solve the need for physical activity of other school children and youths above the age of 15 , for whom education was no longer compulsory. Therefore, a public playground-system was promoted in 1913 in Budapest, but the initiative failed due to the lack of support from the municipality (Fővárosi Közlöny 1913, 1830-1832). As another solution, the larger school playgrounds were permitted to be used by other children, youths and sport clubs during evening hours and on Sundays when schools did not use them (Fővárosi

\footnotetext{
${ }^{6}$ School playgrounds could be visited in the presence of a supervisor, according to a strict schedule, thus, their use differed from the later ones and so from the ones today. The aim of the play-afternoons was mainly to guard children of the lower class while their parents were working. Beyond these social aims, military, defense goals were added after 1907, thus playgrounds became places of also the youths' military training. (VKM Decree of 1900/29.954)
} 
Közlöny 1914, 2110). Thus, school playgrounds of the 1910's can be regarded as prototypical of public playgrounds later installed in public parks and other locations.

The growing need for specialised play areas led to the involvement of the design professions - a scheme of 14 playgrounds were introduced in 1913 for the capital, Budapest. (Figure 4.) These were the first examples to be built according to detailed architectural and landscape architectural plans (Hodászy 1931, 214). The scheme was designed by architect Béla Rerrich (1881-1932), the first teacher of garden design at the Royal Horticultural College. Rerrich, a trained architect, had a widespread international knowledge of the most advanced ideas in both architecture and landscape architecture. During the first decades of the $20^{\text {th }}$ century, he undertook a study tour, and worked with internationally well-known designers such as Thomas Hayton Mawson (1861-1933) in the United Kingdom and René André (1867-1942) in France. He had an in-depth understanding of theoretical developments in Belgium and Germany and, to deepen his knowledge in landscape, he undertook studies in Berlin-Dahlem in 1907. Rerrich's involvement in the design of playgrounds was highly important and changed the Hungarian professional scene. His knowledge of the key European and American examples meant that his ideas were innovative, yet based in thorough understanding of good practice. Playgrounds were no longer built without plans and based only on the guidelines written by educators and health professionals, but were now defined using detailed plans of landscaping, planting, drainage, buildings and equipment (Fővárosi Közlöny 1914, 2110; Rerrich 1919). His school playgrounds were generally divided into two main parts according to gender (boys' and girls' playing fields) and - as opposed to the earlier play areas - equipped with swings and accessories for gymnastics. There was also dedicated space for smaller children with paddling pools and sand hills, while an area for ball games and running was situated in the middle. A small building 
served as a changing room and a playing place during rainy days (Fővárosi Közlöny 1914, 2110). Rerrich put emphasis on the unity of buildings and their surroundings and on artistic design, thus the cooperation of the architect and gardener was important.

Until WW1, four school playgrounds were built according to Rerrich's plans (Fővárosi Közlöny 1914, 2110; Hodászy 1931, 214). The reason for such limited expansion was partly due to the political situation and growing financial difficulties during the war, but the initiative was also hindered by the fact that the Chief Medical Officer thought that public, open playgrounds, used by children from various backgrounds and social classes could harbour and transmit infection (Rerrich 1929, 7). Nevertheless, his four realised playgrounds can be regarded as a great novelty, since as Ludwig Lesser pointed it out- not even in Berlin - where the international influences and English and American examples were more widely known - were any proper playgrounds established before WW1 (Lesser 1927, 13-15).

\section{The inter-war era}

\section{Historical context}

The end of the War and the 'Treaty of Trianon' resulted in the loss of two thirds of Hungary's territory with millions of Hungarian nationals becoming minority population. The question of 'Trianon' and the possibility of its revision was a key public debate in inter-war Hungary. Immediately after WW1, following revolutionary activities and a failed republican attempt, the Hungarian Communist Party took power in March 1919, and ruled for more than four months during the so-called 'Tanácsköztársaság' or 'Hungarian Soviet Republic'. The new regime nationalised every enterprise and asset, including land, artworks and residential houses. It also provided free education and extended voting rights to every adult citizen of the country, including women, for the 
first time in Hungarian history. Despite its initial military successes in re-capturing large parts of the country occupied by allied forces, it failed to maintain the campaign in order to secure its own power. The Hungarian Soviet Republic was swept away by Romanian military forces and a counterrevolutionary government restored the Kingdom of Hungary, headed by a Governor, Miklós Horthy (1868-1957) until the end of WW2.

This period between the two World Wars showed different, controversial directions in public thinking. Whilst during the initial Communist period, social thinking and left-wing principles directed both political and public thinking, after the fall of the so-called Tanácsköztársaság, the main principles changed, and both politics and education emphasised the importance of the 'Christian Nation' and its morals.

\section{Children's spaces for public health and education}

In 1919, during the short period of the Tanácsköztárság, Rerrich published his pamphlet 'Play areas as social duties of landscape architecture and town planning', which placed his theories at the forefront of the political and social context. (Rerrich 1919) In his writing he appealed for spaces and functions for everyone in public parks, and especially for children's playgrounds. His socially sensitive ideas, which were based on the new theoretical writings of the social-democratic Germany, were in accordance with the political aims of the left-wing government (Maass 1981; Scarpa 1981). Rerrich's call to emphasise the importance of 'hygienic' green spaces in cities as opposed to the 'decorative' spaces (based on the categories defined by Camillo Sitte) was parallel to the aim defined in Martin Wagner's dissertation, submitted to the Technische Universität in Berlin in 1915 (Wagner 1915). Both theorists stressed the importance of the 'use value' in case of urban open spaces, foregrounding the needs of the children and their physical health, as opposed to the aesthetic appearance of the open space. Their social agenda also highlighted the requirements of all children from every strata 
of the society.

Rerrich's plans for open public playgrounds were based on his ideas introduced earlier with regard school playgrounds. (Figure 5.) The educational role of these spaces was further enriched by his ideas about planting indigenous species to deepen the knowledge of young citizens about the flora of their native country. The idea of botanical education in the public sphere originated in England, first appearing in the writings of John Claudius Loudon (1822). Botanical education and the use of indigenous plants gained more importance in the shifting representations of nationstates through the end of the $19^{\text {th }}$ and early $20^{\text {th }}$ century, famously exemplified by Gustav Meyer's designs for public parks in Berlin (see Loidl-Reisch [1995] for the German and Austrian context and Csepely-Knorr [2016] for the Hungarian context). The use of native plants became more than botanical education, it played an important part in expressing what is 'Hungarian', and attained more momentum in the context of revisionist ideas in post-WW1 Hungary, similarily to the growing popularity of Willy Lange's work in Germany (Wolschke-Bulmahn 1997, Woudstra 2008). In his theoretical approach, Rerrich used the playgrounds in Great Britain and the American Reform Parks as prime examples. The impact of his campaigning and designs can be measured by the fact, that by the end of the 1930 's, nearly 50 new playgrounds were built across the capital. Referring back to the period before the War, when the playgrounds were rejected on the basis of being 'infectious', Rerrich wrote in the 1920's:

\footnotetext{
"The chief medical office raised an objection [before the War] arguing that playgrounds like these are infectious for children. Today, thanks God, it seems that they are not infectious anymore, but they strengthen children and make them smile and tanned.” (Rerrich 1929, 7)
} 


\section{From philantropic discussions to questions of design}

At the beginning, charitable organisations such as the Hungarian Red Cross and wealthy individuals played a main role in funding public spaces for children (Szokola 1928, 1068). Concerns for the health and hygiene needs of children and young people became widely discussed, with writings on the design theory appearing in most professional journals of landscape architecture, analysing examples of play parks in England, Germany and the USA. The extensive amount of publications and campaigns led to the legal regulation of creating playgrounds in cities. In 1929 the Minister of Culture created a transcript urging cities to create more well-equipped play areas (“Játszóterek létesítése" 1929, 7; "Szabadságot, levegőt" 1930, 105-106). (Figure 6.) This discourse in the papers point to a very significant professional shift. While earlier the pedagogical and educational fields played a leading role in the discussion of children's spaces, in the period between the two World Wars their development was taken over by the design professions. From a philanthropic and educational question, playgrounds became a responsibility of the built environment professions. The growing importance of the question of children's public sphere can be observed through the writings of the new Garden Director of the city of Budapest, Karl August (Károly) Räde (1864-1946). His appeal for the urgency of children's places moved beyond the idea to create playgrounds in existing parks and open spaces; he recommended to create specific, new large scale sports and play areas in densely built areas, by turning brownfield sites into spaces for the youth, to serve their health and give them pleasure (Morbitzer 1932, 5).

The more detailed design of these spaces led to the provision of more sophisticated equipment as well. Whilst initally only sandpits were created, the appearance of water features became widespread, and the placing of artworks, such as statues of famous characters from fairy tales, enriched the playgrounds by the 1930s 
(“A székesfőváros közigazgatása” 1937, 466). Images of the playground in the public park of Tisza Kálmán square, built between 1929-1931, show a complex play structure with opportunities for children to climb, use the slides and play freely. This playground also benefited from the presence and organisation of trained teachers and sports coaches (“Tanítói felügyelet” 1931, 28). (Figure 7.)

\section{From physical to moral education}

The decades between the two World Wars also showed a shift in social and public thinking about the physical education of the children and the role of playgrounds in education. This was parallel to the shifting political ideas of the time. On the one hand, the increasing influence of conservative thinking was apparent in the growing emphasis on the part playgrounds should play in moral education. Instead of health concerns, articles focused on case studies, identifying the effects of outdoor play areas in crime prevention (M. V. 1930, 173). Revisionist ideas and the possibility of another war shifted the emphasis from children as healthy citizens for the future to children as soldiers of the future. This change was not unique to Hungary, with Conway arguing that the launch of the 'National Fitness Campaign' in Britain was seen by some as 'an insidious way of introducing militarism' (Conway 2000, 118.), and Gutman and Coninck-Smith $(2008,4$.) emphasised the role of playgrounds in 'imperialist objectives, for example by training future soldiers and imprinting European values on colonial landscapes'. In Hungary the most explicit example of this approach was published by the landscape architect Kálmán Jonke (1938). In his paper, titled 'Sportgrounds a Concern for Garden Art', Jonke published a plan for a hypothetical sport and play complex (Figure 8.). The functions, installed in a large public park included various sport opportunities, such as training fields for pole-vaulting and high jumping, tennis and bowling courts and football pitches. The axial, strictly geometric plan also gave 
space for children's playgrounds, an open air theatre and a rose garden, surrounded by a woodland area. Both the formal solution of the plan, and the functions were in strong connection with another plan by Martin Wagner and his collaborator Leberecht Migge the Jugendpark (Youth Park), a hybrid of sports park and War memorial, designed in 1916. The Wagner-Migge plan that incorporated functions such as exhibition spaces, memorials, sports grounds and allotment gardens for wounded soldiers, aimed to inspire young generations to fight for the values for which the heroes of World War I gave their lives, and not unimportantly to physically train the 'young for military preparedness' (Haney 2010, 98). As Groening highlighted (2018, 191.), the so-called 'Defence Gardens' (Wehrgärten) were recommended to be created in public parks - similarly to the 'Jugendpark' by Migge and Wagner - to provide space for 'physical and mental military training'. Jonke's plan, that revitalised this idea at a time when fighting for lost values, land and the possibility of a new war was again imminent, contained a 'Heroes' Square', a space for military parades and memorials. As Jonke phrased it, the task proved 'the important role physical education plays in disciplining the nation and the soldiers of the future, as well as the effect sport plays in controlling both the body and the soul' (Jonke 1938). The shift in public thinking is also apparent from the fact that only four years before Jonke's article an essay in the Journal for Educators criticised the Serbian playgrounds for having war-related play equipment, and therefore training soldiers for the future (“Háborús gyermekjátékok” 1934, 182-183). They argued for the removal of soldiers and toy guns from the toy shops, for a better focus on peacetime toys, such as trains or building blocks. Four years later Jonke's rhetoric clearly called for training soldiers of the future. Another four years later Hungary was at war.

\section{Spaces for 'citizens of the future'}

Design theory for school playgrounds originally evolved from theories in the fields of 
pedagogy and various domains of health. When play as a form of physical education appeared, the first playgrounds were imagined on the basis of military training fields and exercise methodologies - empty spaces for working out and later for free running and ball games. The development of play-theory, and most importantly the growing social concerns towards the welfare of children led to the provision of equipment in play areas. These specialised spaces were first tested in Hungary in private school environments during the first decades of the $20^{\text {th }}$ century. The real change in the public playgrounds came just after the WW1 and was informed by the widespread ideas of left-wing politics and social thinking, and the emphasis in creating play areas moved from private school spaces to public areas. During the 1930's the children's public sphere enjoyed a real boom, and a number of new playgrounds were created, originally with the aim to create environments for healthy play for young citizens from all layers of the society. However, with the constant changes in the political scene and the more likely possibility of an upcoming war, the perception of why playgrounds are needed had changed. The strengthening conservative politics of the time resulted in the emphasis on moral education rather than physical, and the fact that Jonke, while arguing for new, professionally designed places used an example from war-time Germany and that he clearly stated the importance these places have in training soldiers of the future. The clear shift from concerns of mental and physical health to concerns of fitness to a new war, and the changing rhetoric around the role public sphere plays in the education of children shows the interwoven nature of the links between socio-political changes and spaces for play. Analysing examples of play spaces and writings about them in the broader historical context of interwar Hungary showed competing visions of future, society and the role children could play in it, and gave a more nuanced understanding of both the histories of playgrounds as spatial entities, and the broader histories of 
organised play.

\section{References:}

Act XXXVIII of 1868 on Public Education, Hungary.

Conway, Hazel. 1991. People's Parks. The Design and Development of Victorian Parks in Britain. Cambridge: Cambridge University Press.

Conway, Hazel. 2000. “Everyday Landscapes: Public Parks from 1930-2000.” Garden History 28 (1): 117-134.

Cranz, Galen 1991. "The Reform Park in the United States (1900-1930)" In The History of Garden Design, edited by Mosser, Monique, and Georges Teyssot, 466-468. London: Thames and Hudson.

Csepely-Knorr, Luca. 2016. Barren Places to Public Spaces. A history of public park design in Budapest 1867-1914. Budapest: Budapest City Archives.

Elliot, B. and K. Fieldhouse. 2000. "Play and Sport.” In Regeneration of Public Parks, edited by Fieldhouse, K., and J. Woudstra, 150-162. London: Taylor \& Francis.

Farquharson, Robert. 1885. School Hygiene and Diseases Incidental to School Life. London.

Felméry, Lajos. 1889. "Iskolai játszóterek berendezése” [Installation of School Playgrounds.] Herkules 6 (11): 81-83.

Fövárosi Közlöny [Capital Gazette] 1913. 24 (50): 1830-1832.

Fövárosi Közlöny [Capital Gazette] 1914. 25 (54): 2110.

Frost, Joe L. 2010. A History of Children's Play and Play Environments. London: Routledge.

Gagen, Elizabeth A. 2000. "An Example to Us All: Child Development and Identity Construction in Early $20^{\text {th }}$-century Playgrounds." Environment and Planning A 32 (4): 599-616.

Georgii, Augustus. 1854. A Biographical Sketch of the Swedish Poet and Gymnasiarch, Peter Henry Ling. London.

Groening, Gert. 2018. "Nature mystification and the example of the 'heroes' groves in early twentieth -century Germany.” In Woudstra Jan and Roth Colin (eds) $A$ History of Groves. London and New York: Routledge, 2018 pp. 184-202.

Gutman, Marta, and Coninc-Smith, Ning de. 2008. "Introduction - Good to Think With - History, Space and Modern Childhood." In Designing Modern Childhoods: 
History, Space and Material Culture of Children, 1-20. Camden: Rutgers University.

Guts-Muths, J. C. F. 1793. Gymnastik für die Jugend. Schnepfenthal.

Guts-Muths, J. C. F. 1796. Spiele zur Übung und Erholung des Körpers und Geistes:

für die Jugend, ihre Erzieher und alle Freunde unschuldiger Jugendfreuden. Schnepfenthal.

“Háborús gyermekjátékok” [Warlike Children’s Toys.] 1934. Néptanítók Lapja [Journal for Educators] 67: 182-183.

Hagner, Dietger. 2004. "Dr. Hermann Rudolph Siebeck (1812-1878) - Aspekte seines gartenkünstlerischen Wirkens.” PhD diss., Institut für Grünplanung und Gartenarchitektur, Leibnitz University of Hannover.

Haney, David. 2010. When modern was green. Life and work of landscape architect Leberecht Migge. London: Routledge.

Hodászy, Miklós. 1931. Budapest székesföváros iskolai és iskolánkívüli testnevelésügyének történeti fejlödése 1890-1930. [The Development History of Physical Education In- and Outside Schools in Budapest 1890-1930.] Budapest: Budapest Székesfőváros.

Howell, Ocean. 2008. "Play Parks. Urban Land Politics and Playgrounds in the United States, 1900-1930.” Journal of Urban History 34 (6): 961-994.

“Játszóterek létesítése” [Creating Playgrounds]. 1929. Újság, January 18, 7.

Jonke, Kálmán. 1938. “Sporttelep létesítése - kertmüvészeti feladat!” [Sportgrounds an Excercise for Garden Art.] Kertészeti Szemle 10: 324-325.

Katona, Ibolya. 2010. “Iskolaegészségügyünk történetéből” [About the History of School Health in Hungary.] In A magyarországi közegészségügy szakterületeinek történetéböl 1876-1944 [About the History of the Fields of Public Health in Hungary 1876-1944], edited by Kapronczay, Károly, 199-200. Budapest.

Kozlovsky, Roy. 2013. The Architectures of Childhood: Children, Modern Architecture and Reconstruction on Postwar England. Farnham: Ashgate.

Krüger, Michael. 1996. "Body Culture and Nation Building: the History of Gymnastics in Germany in the Period of its Foundation as a Nation-State.” The International Journal of the History of Sport 13 (3): 409-417.

Lesser, Ludwig. 1927. Volksparke heute und morgen. Berlin-Zehlendorf: Rembrandt Verlag. 
Loidl-Reisch, Cordula. 1995. "Wiener Stadtparks um 1900. Am Beispiel von Türkenschantzpark und Elisabeth-Denkmal (Volksgarten)" Die Gartenkunst 7 (2): 298-308.

Loidl-Reisch, Cordula. 2007. "Stadtparks in Wien und Österreich 1867-1918." In Stadtparks in der österreichischen Monarchie 1765-1918, edited by Hajós, Géza, 83-120. Wien: Böhlau.

Loudon, J. C. 1822. An Encyclopaedia of Gardening. London.

Maass, Inge. 1981. "People's Parks in Germany. City and Open Air Culture in the Open Space." Lotus International 30 (1): 123-128.

Mero, Everett B. 1908. American Playgrounds. Their Construction, Equipment, Maintenance and Utility. Boston.

Morbitzer, Dezső. 1932. “Az ötven éves székesfővárosi kertészet” [The 50-Year-Old Horticulture of the Capital.] Független Budapest 27 (1): 5.

M. V. 1930. “A játszóterek jótékony hatása a közerkölcsökre” [The Positive Effect of Playgrounds on Public Morality.] Városi Szemle 16: 173.

Ohmann, Oliver. 2008. Turnvater Jahn und die Deutschen Sportfeste. Erfurt: Sutton. Pérez de Arce, Rodrigo. 2018. City of Play. London: Bloomsbury.

Pfister, Gertrud. 2003. “Cultural Confrontations: German Turnen, Swedish Gymnastics and English Sport - European Diversity in Physical Activities from a Historical Perspective." Culture, Sport, Society 6 (1): 61-91.

Rerrich, Béla. 1913. “A székesfővárosi Aréna úti játszótér és üdülőhely” [Playground and Resort at Aréna Street in Budapest.] Magyar Építömüvészet 11 (1): 30-32. Rerrich, Béla. 1919. “A játéktér mint szociális irányú városépitészeti és kertmüvészeti feladat” [Play Areas as Social Duty in Town Planning and Garden Design.] Budapest.

Rerrich, Béla. 1929. “Gyönyörü a Gellérthegy” [The Gellért Hill is Beautiful.] Pesti Hírlap 51 (209): 7.

Salzmann, C. G. 1796. Konrad Kiefer oder Anweisung zu einer vernünftigen Erziehung. Schnepfenthal.

Salzmann, C. G. 1808. Über die Erziehungsanstalt zu Schnepfenthal. Schnepfenthal. Scarpa, Ludovica. 1981. "Quantifying Parkland. The Standards of Happiness in Socialdemocratic Berlin.” Lotus International 30 (1): 118-122. 
Spencer-Wood, Suzanne M. 1994. "Turn of the Century Women's Organizations, Urban Design, and the Origin of the American Playground Movement" Landscape Journal 13 (2): 124-137.

“Szabadságot, levegőt, egészséget a pesti gyermekeknek!” [Freedom, Air and Health for Children in Pest!] 1930. Újság, July 7, 105-106.

“A székesfóváros közigazgatása az 1934. évben” [Public Administration of the Capital in 1934.] 1937. Budapesti Statisztikai Közlemények [Statistical Bulletin of Budapest] 78 (2): 1-608.

Szokola, Leó. 1928. "A hatóságok és a társadalom szociális munkájának kapcsolata” [The Connection Between Authorities and the Social Work of Society.] Városi Szemle 14: 1030-1052.

"Tanítói felügyelet a fóvárosi játszótereken" [Teacher Control at Playgrounds of the Capital.] 1931. Néptanitók Lapja 64 (19): 28.

VKM Decree of 1900/29.954, Hungary.

Wagner, Martin. 1915. "Das sanitäre Grün der Städte, ein Beitrag zur Freiflächentheorie.” PhD diss., Königlichen Technischen Hochschule, Berlin.

Wolschke-Bulmahn, Joachim. 1997 "The Nationalization of Nature and the Naturalization of the German Nation: "Teutonic" Trends in Early TwentiethCentury Landscape Design", in J. Wolschke-Bulmahn (ed), Nature and Ideology. Natural Garden Design in the Twentieth Century, Washington DC: Dumbarton Oaks Research Library and Collections, pp. 187-219.

Woudstra, Jan. 2008 "The changing nature of ecology: a history of ecological planting (1800-1980)" in: N. Dunnett, - J. Hitchmough (eds), The Dynamic Landscape: Design Ecology and Management, London: Spon Press, pp. 23-57. 


\section{Dr Luca Csepely-Knorr}

Dr Luca Csepely-Knorr is a reader at the Manchester School of Architecture. She studied landscape architecture (Corvinus University, Budapest), art history (Eötvös Loránd University, Budapest) and art and design (Manchester Metropolitan University) and is particularly interested in international knowledge transfer in landscape and urban design theory during the twentieth century. Her book Barren Places to Public Spaces: A History of Public Park Design in Budapest 1867-1914 (Budapest: Budapest City Archives, 2016) describes the evolution of Hungarian public park design and theory in an international context.

Contact

Luca Csepely-Knorr

Manchester School of Architecture, Manchester Metropolitan University

Chatham Building, Cavendish Street, M15 6BR

UK

1.csepely-knorr@mmu.ac.uk

\section{Dr Maria Klagyivik}

Dr Maria Klagyivik is a landscape architect. Her research focusses $19-20^{\text {th }}$ century institutional and provate gardens in Hungary: her $\mathrm{PhD}$ dissertation examined the history of open spaces in educational settings in Hungary between 1868-1945. She works at the Hungarian Heritage Protection and Development Nonprofit Ltd. in Budapest, Hungary as landscape architect, where currently she is working on the historical research, renovation and reconstruction of several historic gardens in the National Castle Program and National Fortress Program of Hungary. 